\title{
Thixotropic evaluation of bentonitic clay dispersions modified with nonionic surfactants for organic drilling fluids
}

\section{(Avaliação tixotrópica de dispersões de argilas bentoníticas modificadas com tensoativos não iônicos para fluidos de perfuração orgânica)}

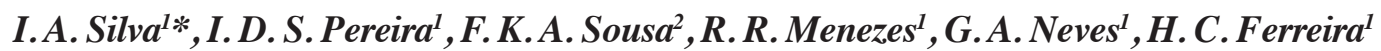 \\ ${ }^{I}$ Federal University of Campina Grande, Academic Unit of Materials Engineering, 58109-970, \\ Campina Grande, PB, Brazil \\ ${ }^{2}$ Federal University of Campina Grande, Academic Unit of Production Engineering, Campina Grande, PB, Brazil
}

\begin{abstract}
The use of nonionic surfactants to modify the surface of bentonite is still quite restricted, although many advantages of that method can be found in the literature, like superior stability and low toxicity. On the other hand, problems involving the fluidity and viscosity of dispersions used in organic drilling fluids have become more and more challenging to colloid science. Therefore, the present study had the purpose of assessing the thixotropic behavior of dispersions of Brazilian bentonite organophilizated with nonionic surfactants for use in organic drilling fluids. Bentonite samples were organophilizated by a combination of two nonionic surfactants, being the process evaluated by X-ray diffraction and thermogravimetric analysis, in which the amount of nonionic surfactants incorporated was quantified. Fluid evaluation followed current standards. The flow curves of the organophilic clays revealed pseudoplastic behavior and the presence of hysteresis, which suggested thixotropy, with a relation between the thixotropy and the apparent viscosity of the final dispersions. Most of the process parameters evaluated showed significant effects on the value of $\mathrm{d}_{001}$ and the overall performance. Factors like clay type and organophilization method also directly affect the thixotropic behavior of dispersions. One of the samples can be considered promising for use in organic drilling fluids.
\end{abstract}

Keywords: organophilic clay, nonionic surfactant, thixotropy, drilling fluids.

Resumo

O uso de tensoativos não iônicos na modificação superficial de argilas bentoníticas ainda é bastante restrito, embora haja na literatura algumas de suas vantagens, por exemplo, maior estabilidade térmica e baixa toxicidade. Como também, problemas com fluidez e viscosidade de dispersões para uso em fluidos de perfuração orgânicos são cada vez mais desafiadores para a ciência coloidal. Diante disto, esse trabalho teve o objetivo de avaliar o comportamento tixotrópico das dispersões de argilas bentoníticas brasileiras organofilizadas com tensoativos não iônicos para fluidos de perfuração orgânicos. Argilas bentoníticas foram organofilizadas com combinação de dois tensoativos não iônicos, cujo processo de organofilização foi avaliado por difração de raios $X$ e análise termogravimétrica; neste último, os teores de tensoativos não iônicos incorporados foram quantificados. A avaliação dos fluidos seguiu as normas vigentes da Petrobras e API. Os resultados de curvas de fluxo das argilas organofílicas mostraram comportamento pseudoplástico e a presença de histerese, indicando presença de tixotropia, havendo relação entre a tixotropia e a viscosidade aparente das dispersões obtidas. A maioria dos parâmetros de processo avaliados mostrou efeitos significativos sobre o valor de $d_{001}$ e o rendimento do processo. Fatores como tipo de argila e processo de organofilização também influenciaram diretamente o comportamento tixotrópico das dispersões. Uma amostra se mostrou promissora para uso em fluidos de perfuração base orgânica. Palavras-chave: argilas organofílicas, tensoativos não iônicos, tixotropia, fluidos de perfuração.

\section{INTRODUCTION}

Organophilic clay is clay intercalated with organic matter so as to achieve improved adsorption properties (e.g. increased shear rate, viscosity and resistance to the gel of organic drilling fluids), thus making them suitable for a wide range of applications [1]. Ionic surfactants are commonly used in the surface modification process, which makes clay dispersible in organic media. Ratkievicius et al.

*isabelle_albuquerquecg@hotmail.com
[2] studied clays organophilizated with ionic surfactants and observed that temperature is the factor that most affects the rheological properties of fluids prepared with organophilic clays. An analysis of the studies involving ionic and nonionic surfactants with respect to thixotropy, although there are not many in the literature, reveals that nonionic surfactants lead to a higher chemical and thermal stability $[3,4]$, low toxicity and latent biodegradability [5], since they are derivatives of non-aromatic alcohol ethoxylate [59], preserve exchangeable inorganic cations after adsorption $[10,11]$, with the possibility of cation exchange between the clay organophilizated with nonionic surfactant and inorganic 
cations [7, 11, 12], among other advantages. These properties are so useful that make clays organophilizated with nonionic surfactants suitable for many applications, among which the use as organic and inorganic residue adsorbent, due to their hydrophilic-hydrophobic nature $[4,5]$, in drilling fluids [6], and for production of clay-polymer nanocomposites [13] can be highlighted.

Oil-based drilling fluids were initially obtained using organophilic clays modified with quaternary ammonium salts; however, these salts have some limitations that nonionic surfactants do not exhibit, such as low thermal stability and high resistance to degradation when discarded in the environment, thus being successfully introduced into the formulations for organic drilling fluids. In addition, larger basal spacings and larger amounts of organic carbon can be obtained in organophilic bentonites using nonionic surfactants [6]. Besides microstructure, rheology remains as one of the most challenging problems in colloid science, since the flow has the ability to induce reversible and irreversible structural changes in the dispersions, thus being more and more necessary to control the fluidity and viscosity features [14]. A variable viscosity is the manifestation of structural changes induced by the flow. When changes are reversible and depend on time, this effect is called thixotropy [15]. A relative measurement of thixotropy is hysteresis, since the area and the shape of the hysteresis loop may present sharp variations depending on the material, test conditions, shear history at the beginning of the evaluation, maximum shear rate and acceleration rate [16]. Drilling fluids are expected to have thixotropic behavior; therefore, it becomes paramount, besides rheology, the study of the thixotropic behavior of suspensions made of clays organophilizated with nonionic surfactants. The present work proposes the thixotropic evaluation of dispersions made of Brazilian bentonite clays from new occurrences applied to organic drilling fluids, so as to complement and confirm a previous rheology study [6].

\section{MATERIALS AND METHODOLOGY}

For the present study, four bentonite samples, referred to as Bent1, Bent2, Bent3 and Bent 4 were used. These samples were supplied by Bentonit União Nordeste, Paraíba, Brazil. The physical, chemical and mineralogical characterizations of the in natura clays were determined in [6]. The samples presented the following mineralogical phases: smectite, kaolinite and quartz and amounts of $\mathrm{Fe}_{2} \mathrm{O}_{3}$ below $8 \%$. Regarding the particle sizes distribution (GA), the clays presented average diameter varying from 3.3 to $12.2 \mu \mathrm{m}$. The cation exchange capacity (CEC) of the clays, measured by the methylene blue method, varied from 56 to $64 \mathrm{meq} / 100 \mathrm{~g}$ and a surface area (SA) of 477 to $499 \mathrm{~m}^{2} / \mathrm{g}$. In the organophilization process, a combination of the nonionic surfactants Ultramina 20 (TA20), ethoxylated amine TA20, $100 \%$ active matter, and Ultramina 50 (TA50), ethoxylated amine TA50, 100\% active matter, supplied by Oxiteno, Brazil, in the proportion of $23.0 \%$ (dry clay weight), using the mixture (50\% TA20 +50\% TA50), was used. The liquid organic dispersant media used was commercial diesel, with a density of $0.853 \mathrm{~g} / \mathrm{cm}^{3}$ at $25^{\circ} \mathrm{C}$. Silva et al. [6] observed that both the combination of the surfactants TA20+TA50 at $23.0 \%$ (dry clay weight) and the use of diesel as organic dispersant media led to the best results, favoring better apparent viscosity (AV) of the dispersions for use in organic drilling fluids. Fig. 1 illustrates the structural formulas of the nonionic surfactants.<smiles>CCCCCCCCCO</smiles><smiles>CCCCCCCCCOCCO</smiles>

Figure 1: Structural formulas of the nonionic surfactants used: (a) TA20; and (b) TA50.

[Figura 1: Fórmulas estruturais dos tensoativos não iônicos utilizados: (a) TA20; $e$ (b) TA50.]

The organophilization process involved the use of 3.6 $\mathrm{L}$ of deionized water and $150 \mathrm{~g}$ of clay; the mixture was shaken for $20 \mathrm{~min}$ (at $17500 \mathrm{rpm}$ ), after which the nonionic surfactant combination was added. The $\mathrm{pH}$ was set to 7.0 with an $\mathrm{HCl} 2 \mathrm{~N}$ solution and the shaking was kept for another $20 \mathrm{~min}$ (at $1600 \mathrm{rpm}$ ), and then the system was filtered. The organophilic clays were not washed, being taken directly to dry in a stove at $60{ }^{\circ} \mathrm{C}$ for a period between 24 and $86 \mathrm{~h}$. After that, they were ground and sieved in ABNT 200 sieve $(0.074 \mathrm{~mm})$. The organophilizated bentonite samples were characterized by X-ray diffraction (XRD, Shimadzu, D6000) to evaluate the changes in the interplanar basal distance $\left(\mathrm{d}_{001}\right)$. The test was conducted using $\mathrm{CuK} \alpha$ radiation, fixed-time scanning mode (step of $0.02^{\circ} 2 \theta$ and counting time of $0.6 \mathrm{~s}$ ), $0.5^{\circ}$ divergence, anti-scatter slits and $0.15 \mathrm{~mm}$ receiving slit, using $40 \mathrm{kV} / 30 \mathrm{~mA}$ monochromator. The window of experimental error was about $\pm 0.03 \AA$ at $2 \theta$ of $28.2^{\circ}$. The percentage of surfactant incorporated in the clay was determined by thermogravimetric analysis (TG, Shimadzu, 60H), subtracting the loss of weight of the natural clays from their respective organophilic counterparts in the range corresponding to the decomposition of a nonionic surfactant, between 180 and $1000{ }^{\circ} \mathrm{C}$. The samples were sieved in ABNT 200 sieve $(0.074 \mathrm{~mm})$, heated up at $1000{ }^{\circ} \mathrm{C}$ using a heating rate of $10^{\circ} \mathrm{C} / \mathrm{min}$, under a nitrogen atmosphere up to $600{ }^{\circ} \mathrm{C}$ and under air up to $1000^{\circ} \mathrm{C}$.

The organic drilling fluids were prepared as follows: 336 $\mathrm{mL}$ of liquid organic media and $84 \mathrm{~mL}$ of a saturated $\mathrm{NaCl}$ solution $(0.395 \mathrm{~g} / \mathrm{mL})$ were poured into a Hamilton Beach N5000 shaker and mixed for $5 \mathrm{~min}$, producing the organic fluid (emulsion), with the aging of $24 \mathrm{~h}$. The apparent viscosity (AV) values complied with Petrobras' standards $[17,18]$. The measurements of the flow curves (shear stress 
$\mathrm{x}$ shear rate) were obtained in $\mathrm{kPa}$ by means of a Fann 35A viscometer, as determined by Petrobras' standard [17] for organic drilling fluids. After aging, the base mud was shaken for $5 \mathrm{~min}$ and poured into the viscometer for determination of the deflections at 3,6,100, 200,300 and $600 \mathrm{rpm}$ in order to plot the flow curves. The thixotropy value was determined by subtracting areas in both directions of the flow curves.

\section{RESULTS AND DISCUSSION}

Fig. 2 illustrates the XRD curves of the in natura bentonite samples added with the combination of surfactants TA20+TA50-23\%. One may notice that the in natura samples presented basal reflection of the angle $2 \theta$ varying from $5^{\circ}$ to $7^{\circ}$, which corresponded to a distance $\mathrm{d}_{001}$ between the layers varying, approximately, between $13.1 \AA(1.31 \mathrm{~nm})$ and 15.5 $\AA$ ( $1.55 \mathrm{~nm})$. The addition of the surfactant caused a shift of this reflection to lower angles, which indicated that the organophilization process was effective. The value of $d_{001}$ was enhanced both by the intercalation of surfactants and by the conformations of the species in the clay minerals. Most of the process parameters had significant effects on the value of $d_{001}$ and the performance of the process. Some samples presented a second slight diffraction reflection, indicating that some layers were more easily intercalated with the surfactant, while others were not, thus generating different basal distances [6, 19]. The heterogeneous distributions of loads directly affect the adsorption of surfactants in the silicate layers, and the surfactant adsorption mechanisms at the surface are related to the interaction of the ion-dipole (i.e., the compensation cation present in the clays), formation of hydrogen bridge bonds, van der Waals effect, and entropy raise effects $[2,6,8,20]$. However, a considerable increase in the basal spacing was observed, which suggested not only the effective adsorption at the edges or outer layers, but also the penetration of the surfactants between layers, in spite of the long carbon chains surfactants used [6]. Alves et al. [8, 21] confirmed that washing stages in the organophilization process, regardless of employing just deionized water or an ethanol/water solution, besides removing part of the adsorbed surfactant, is also capable of modifying the structure of the intercalated areas, thus reducing the value of $\mathrm{d}_{001}$; they also highlight that washing stages must be reduced or eliminated from the organophilization process, since they compromise some properties, are costly and have negative environmental impact.

Fig. 3 illustrates TG and DTG curves of the bentonite samples added with nonionic surfactants. Multiple decomposition stages of the organic matter (around 200, 300,400 and $500{ }^{\circ} \mathrm{C}$ ) were observed, confirming what was previously noticed (XRD), that is, the surfactant was adsorbed not only between the layers but at other surfaces of the material [6]. Between 30 and $180{ }^{\circ} \mathrm{C}$, the loss of solvent, probably ethoxylated alcohol, was observed; between 200 and $600{ }^{\circ} \mathrm{C}$, the decomposition of the organic structure with $100 \%$ mass loss occurred. The values of mass loss are presented in Table I. In the DTG curves, a

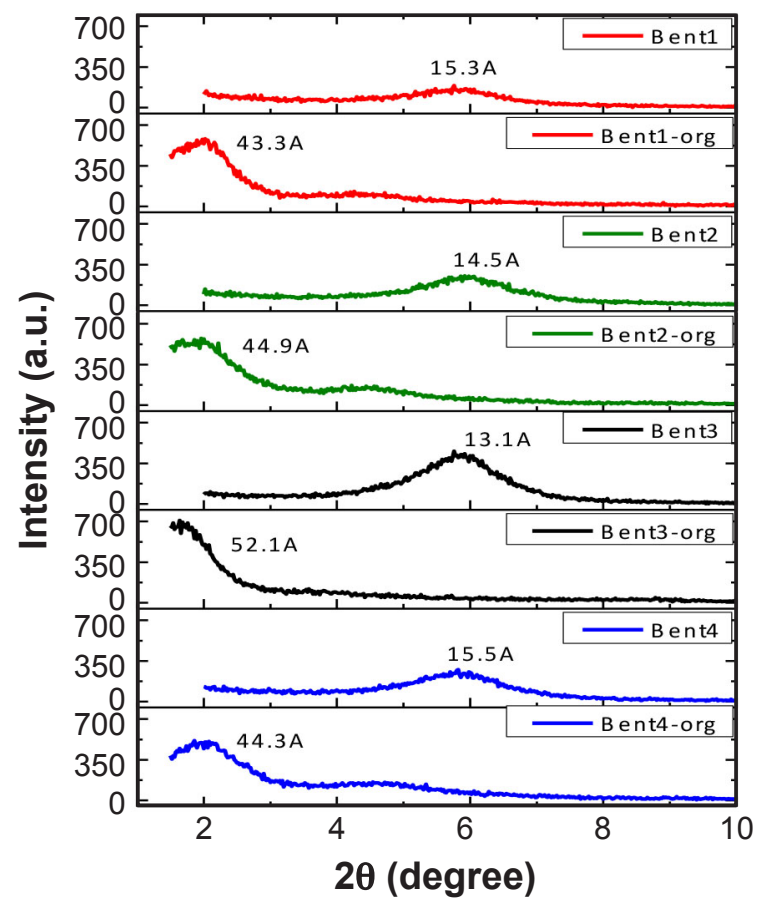

Figure 2: X-ray diffraction patterns of in natura and organophilic bentonite samples.

[Figura 2: Diftatogramas de raios $X$ das amostras bentoniticas in natura e organofílicas.]

drastic intensity increases for the sample Bent 2 at about $340{ }^{\circ} \mathrm{C}$ was detected, which can be associated to strong interactions existing between the amine groups of the surfactants and hydrogen of $\mathrm{SiOH}$ at the edges and layers of the sample [8,21-23] and/or interaction by peripheral iondipole intercalation $[8,21,24]$. Besides, since there was no washing in the organophilization process, this peak can also be associated with non-incorporated species of amine of the surfactants that were adsorbed at the surface of the sample; nevertheless, when there are strong interactions between the surfactant and the clay, mere washings are not capable of removing non-incorporated species $[8,21]$. The high values of CEC, SA and clay content in the GA of the sample Bent2

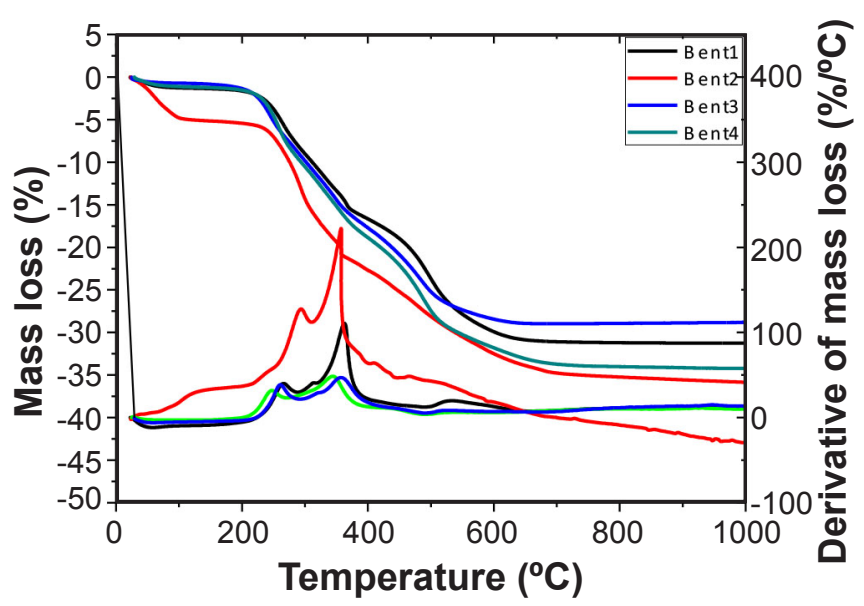

Figure 3: TG and DTG of the organophilic samples under study. [Figura 3: TG e DTG das amostras organofílicas em estudo.] 
Table I - Results obtained by TG.

[Tabela I - Valores referentes aos resultados obtidos por TG.]

\begin{tabular}{ccccc}
\hline Sample & $\begin{array}{c}\text { Mass } \\
\text { loss }(\%)\end{array}$ & $\begin{array}{c}\text { Added } \\
\text { surfactant }(\%)\end{array}$ & $\begin{array}{c}\text { Incorporated } \\
\text { surfactant }(\%)\end{array}$ & $\begin{array}{c}\text { Non-incorporated } \\
\text { surfactant }(\%)\end{array}$ \\
\hline Bent1-org & 31.32 & 23.00 & 21.45 & 1.55 \\
Bent2-org & 26.82 & 23.00 & 20.89 & 2.11 \\
Bent3-org & 28.82 & 23.00 & 21.44 & 1.56 \\
Bent4-org & 34.32 & 23.00 & 21.40 & 1.60 \\
\hline
\end{tabular}

suggested that strong interactions between the clay and the surfactant were the reason for the drastic rise in the intensity in the DTG of this sample. Anyway, the rheological and thixotropic results can confirm if, in fact, such interaction occurred. Table I presents the values of mass loss, added surfactant, incorporated and non-incorporated surfactant of the organophilic samples obtained by TG. It was observed that the percentage of added and incorporated surfactant had very close values, and also that these percentages were similar among the different samples. Since the sample Bent2 had superior characterization results compared to other samples [6,25], but its amount of incorporated surfactants was similar to other samples, the previous results were therefore confirmed.
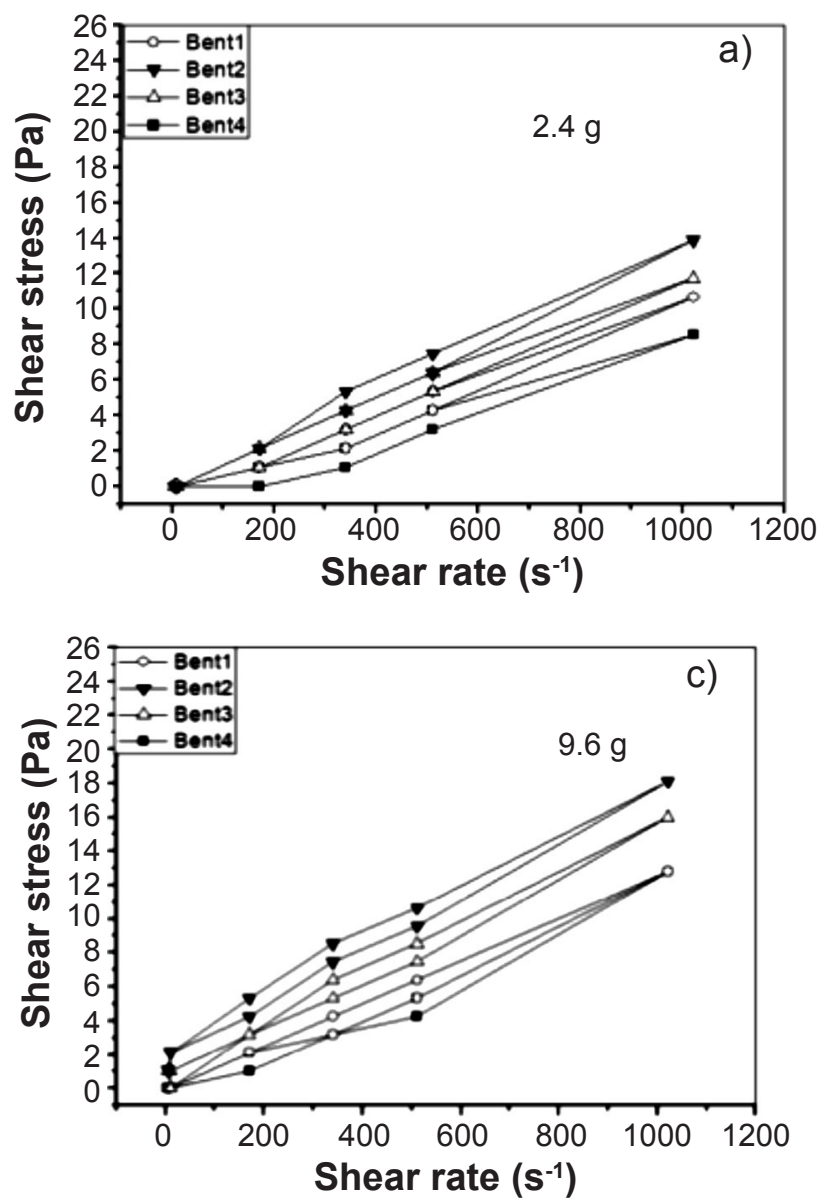

Among the analysis techniques that could be applied to the data, we chose to obtain the shear stress $\mathrm{x}$ shear rate curve (flow curve, Fig. 4), which allowed performing a comparative analysis of the time-dependent behaviors of the samples. Fig. 4 illustrates as flow curves of the dispersions of organophilic clay samples Bent1, Bent2, Bent3 and Bent4, in the proportions of 2.4, 6.0,9.6 and $13.2 \mathrm{~g}$, established by oil field standards $[17,18]$. As one can notice, the viscosity of the fluid increased due to a rise in the concentration of this clay, while it decreased with a rise in the shear rate. Those are well-defined curves, which had a pseudoplastic behavior and hysteresis between the forward and backward cycles. This was related to the thixotropy phenomenon, where probably occurred a face-to-edge interaction between the
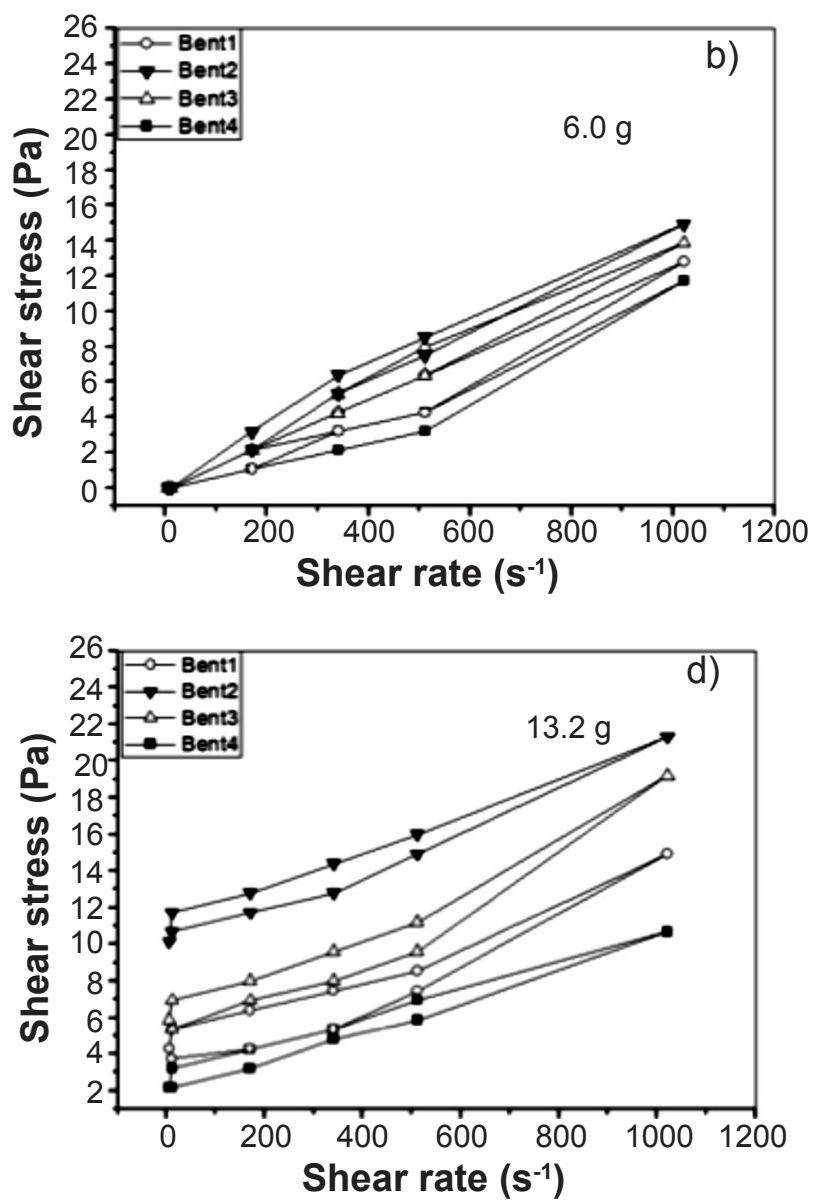

Figure 4: Flow curves of the organophilic clay dispersions. [Figura 4: Curvas de fluxo das dispersões de argilas organofílicas.] 
Table II - Thixotropy and apparent viscosity (AV) values of the organophilic clay dispersions.

[Tabela II - Valores de tixotropia e viscosidade aparente (VA) das dispersões de argilas organofílicas.]

\begin{tabular}{ccccc}
\hline Clay & $\begin{array}{c}\text { Content } \\
(\mathrm{g})\end{array}$ & $\begin{array}{c}\text { Standard } \\
\text { AV (Pa.s) }\end{array}$ & $\begin{array}{c}\text { Obtained } \\
\text { AV (Pa.s })\end{array}$ & $\begin{array}{c}\text { Thixotropy } \\
\left(\text { Pa. }^{-1}\right)\end{array}$ \\
\hline \multirow{6}{*}{ Bent1 } & 2.4 & 0.006 & 0.0065 & 532 \\
& 6.0 & 0.008 & 0.0065 & 567 \\
& 9.6 & 0.011 & 0.0075 & 718 \\
& 13.2 & 0.016 & 0.0075 & 756 \\
\hline \multirow{5}{*}{ Bent2 } & 2.4 & 0.006 & 0.0060 & 719 \\
& 6.0 & 0.008 & 0.0090 & 901 \\
& 9.6 & 0.011 & 0.0115 & 1212 \\
Bent3 & 13.2 & 0.016 & 0.0165 & 1126 \\
& 2.4 & 0.006 & 0.0070 & 721 \\
& 6.0 & 0.008 & 0.0110 & 802 \\
& 9.6 & 0.011 & 0.0110 & 835 \\
Bent4 & 13.2 & 0.016 & 0.0120 & 913 \\
\hline & 2.4 & 0.006 & 0.0060 & 340 \\
& 9.6 & 0.008 & 0.0065 & 387 \\
& 13.2 & 0.011 & 0.0065 & 409 \\
\hline
\end{tabular}

particles and therefore a rise in viscosity, which means a more prominent deflection over the time necessary to stabilize the deflector of the viscometer and get a measurement [26, 27]. So, the suspensions of all the samples presented thixotropy and not rheopecty. It is possible to observe that the curves of dispersions of the samples Bent 2 and Bent 3 had the best behaviors, with higher hysteresis, which is an indication of higher thixotropy [26]. On the other hand, the curves of the dispersions with the samples Bent1 and Bent4 had the worst results, having lower hysteresis. It is also noticeable that the rise in the clay content $(2.4,6.0,9.6$ and $13.2 \mathrm{~g})$ lead to a rise in the slope of the curve, due to the necessity of higher shear rates, also increasing the development of thixotropy. This result showed that the rise in the clay content of the dispersion affected the thixotropic potential, confirming the characterization results found for the sample Bent2 [6, 25]. It also proved that the interactions that occurred during the organophilization process (Figs. 2 and 3, and Table I) had a direct influence on the rheological and thixotropic results.

Table II presents the apparent viscosity (AV) and thixotropy values of the organophilic clay dispersions. By the flow curves (Fig. 4), a comparison between the thixotropy values of the present study and the viscosity values found in [6] could be established. Analyzing Table II, it can be observed that there is a relation between the thixotropy and apparent viscosity values of the dispersions, that is, higher thixotropy values also corresponded to higher
$\mathrm{AV}$ values. The best results were found for the dispersions of sample Bent2, meeting the standards of the oil field $[17,18]$ in all proportions. The dispersions with sample Bent 3 had good results too, but did not achieve the specifications for all proportions; then, Bent1 and Bent4 had the worst results for thixotropy and, consequently, AV. According to [19], factors such as surface polarity, amount of organic matter, basal spacing, amount of incorporated surfactant, thermal stability, among others, may affect both the properties of the organophilic clays and the rheological properties of their dispersion, as previously seen. Besides, the most active cations of the intermediate layers of the clays are more efficiently modified and are subjected to better properties.

The organic fluids made of organophilic clays have rheological behavior that depends not only on the shear rate (pseudoplastic and dilatant) but also on time, which is known as thixotropy. Thixotropic fluids present a viscosity increment at rest, due to the formation of the gel state, and recovery of fluidity (solid state), when subjected to dynamic conditions (shear). Most of the organic drilling fluids exhibit this property due to the appearance of attractive forces between the organophilic clay particles and the organic media, to the low shear rates (slow flow or at rest). Such attraction is possible because the distribution of electric charges on the surface of the clays is not uniform, presenting residual negative charges on the faces and positive ones at the edges [28].

\section{CONCLUSIONS}

Based on the thixotropic study of dispersions made of bentonite modified with nonionic surfactants for use in organic drilling fluids, it can be concluded that the determination of the apparent viscosity (AV) values and flow curves are fast and efficient methods to understand the rheological and thixotropic behavior of organophilic clay dispersions. The flow curves revealed pseudoplastic behavior and the presence of hysteresis, suggesting thixotropy, with higher thixotropy values corresponding to higher AV. Dispersions of organophilic sample Bent 2 had the best rheological and thixotropic results, due to the use of the mixture of nonionic surfactants, meeting the standard considered in this study and having great potential as viscosifier agent in organic drilling fluids. It is highlighted that the type of clay and the organophilization method directly affect the thixotropic behavior of the dispersions since the values of $\mathrm{d}_{001}$ were enhanced both by the intercalation of surfactants and by the conformation of species in the clay minerals. Most of the process parameters analyzed showed significant effects on the value of $\mathrm{d}_{001}$ and the performance of the process.

\section{REFERENCES}

[1] G. Zhuang, Z. Zhang, M. Fu, X. Ye, L. Liao, Appl. Clay Sci. 116-117 (2015) 257.

[2] L.A. Ratkievicius, F.J.V. Cunha Filho, E.L Barros Neto, V.C. Santanna, Appl. Clay Sci. 135 (2017) 307. 
[3] G.W. Beall, M. Goss, Appl. Clay Sci. 27 (2004) 179.

[4] R. Guégan, M. Giovanela, F. Warmont, M. MotelicaHeino, J. Colloid Interface Sci. 437 (2014) 71.

[5] Y.H. Shen, Chemosphere 44, 5 (2001) 989.

[6] I.A. Silva, F.K.A. Sousa, R.R. Menezes, G.A. Neves, L.N.L. Santana, H.C. Ferreira, Appl. Clay Sci. 95 (2014) 371.

[7] R. Guégan, M. Giovanela, Mater. Res. 19,6 (2016) 1324. [8] J.L. Alves, P.D.T.V.E. Rosa, A.R. Morales, Appl. Clay Sci. 132-133 (2016) 475.

[9] G. Zhuang, Z. Zhang, H. Wu, H. Zhang, X. Zhang, L. Liao, Colloids Surf., A 518 (2017) 116.

[10] R.R. Rocha, A. Zanardo, M.M.T. Moreno, Cerâmica 54, 331 (2008) 332.

[11] R. Guégan, M. Gautier, J.M. Beny, F. Muller, Clays Clay Miner. 57 (2009) 502.

[12] Y. Deng, J.B. Dixon, G.N. White, Clays Clay Miner. 51 (2003) 150.

[13] S. Chakraborty, P.P. Mallick, S. Dasgupta, R. Mukhopadhyay, Int. J. Polymer. Mater. 62 (2013) 220.

[14] C.P. Whitby, P.C. Garcia, Appl. Clay Sci. 96 (2014) 56.

[15] N. Cruz, Y. Peng, Miner. Eng. 98 (2016) 137.

[16] J. Mewis, N.J. Wagner, Adv. Colloid Interface Sci. 147148 (2009) 214.

[17] Petrobras, "Argila organofílica para fluidos de perfuração à base de óleo especificação e método de ensaio", EP-1EP-00023-A (2011).

[18] API, "Recommended practice for field testing oil-based drilling fluids", 13B-2 (2012).

[19] Q. Zhou, R.L. Frost, H.P. He, Y.F. Xi, Colloid Interface Sci. 307 (2007) 50.

[20] S.Y. Lee, S.J. Kim, Colloids Surf., A 211 (2002) 19.

[21] J.L. Alves, P.T.V. Rosa, A.R. Morales, Appl. Clay Sci. 150 (2017) 23.

[22] W. Xie, Z. Gao, W. Pan, D. Hunter, A. Singh, R. Vaia, Chem. Mater. 13 (2001) 2979.

[23] W, Xie, R. Xie, W. Pan, D. Hunter, B. Koene, L. Tan, R. Vaia, Chem. Mater. 14 (2002) 4837.

[24] S. Livi, J. Duchet-Rumeau, J.F. Gérard, J. Colloid Interface Sci. 353 (2011) 225.

[25] I.A. Silva, J.M.R. Costa, R.R. Menezes, H.S. Ferreira, G.A. Neves, H.C. Ferreira, Rev. Esc. Minas 66 (2013) 485.

[26] R.R. Menezes, L.F.A. Campos, H.S. Ferreira, L.N. Marques, G.A. Neves, H.C. Ferreira, Cerâmica 55 (2009) 349.

[27] L.B. Paiva, A.R. Morales, F.R. Valenzuela Diaz, Appl. Clay Sci. 42 (2008) 8.

[28] P. Souza Santos, Ciência e tecnologia de argilas, 2ª Ed., Vol. 1, Edgar Blücher, S. Paulo (1992).

(Rec.07/12/2017, Rev. 02/02/2018, Ac. 17/02/2018) 